Orfanic compounds in the early atmosphere formed abiotically from atomic carbon

(ieol. Rundschau 71 1-21

KATHRFIN, H. (1982):

Structures and properties of defects in magnesium oxide associated with carbon and hydrogen

Ph. D. Thesis Univ. Cologne (in German)

KATHREIN H., GONSKA H., and FREUND F. (1982): Subsurface segrefation and diffusion of carbon in magnesium oxide
J. Appl. Phys. (A) accepted for publication OBERHEUSER G. (1982):

Carbon, excess oxygen and $\mathrm{OH}^{-}$ions in olivine single crystals

Ph. D. Thesis Univ. Cologne (in German)

WFNGELER h., KNOBEL R., KATHREIN H., FREUND F., DEMOPTIEF G. and WOLFF G. (1982):

Atomic carbon in mapnesium oxide single crystals - depth profiling, temperature and time-dependent behavior

J. Phys. Chem. Solids 43 59-71

H14

\title{
METASOMATISM IN THE MANTLE BENEATH PIPE 200, NORTHERN LESOTHO
}

\section{E.S. SCHANDL,}

Dept. of Geological Sciences, McGill University, Montreal, P.Q., Canada

D.B. CLARKE,

Dept. of Geology, Dalhousie University, Halifax, N.S., Canada

\section{Introduction}

Peridotite nodules in kimberlite contain information about the equilibria or disequilibria that prevailed in the mantle just prior to eruptio If a nodule shows signs of physical (textural) or chemical disequilibrium, then information may potentially be obtained on two or more processes which had affected the mantle in the vicinity of its origin, including the timing of those events. This is the case with a small number of nodules from Pipe 200, including some described by Carswel et al. (1979) and Mitchell et al. (1980).

The Pipe 200 (PTH) nodules consist of garnet therzolite, garnet-chromite lherzolite, chromite lherzolite and spinel harzburgite. The rocks generally have low modal percentages of clinopyroxene and garnet, low $\mathrm{Al}_{2} \mathrm{O}_{3}, \mathrm{CaO}$ and $\mathrm{Na}_{2} \mathrm{O}$, high $100 \mathrm{Mg} /(\mathrm{Mg}+\mathrm{Fe})$ values of $91.0-95.4$ and high 100 $\mathrm{Cr} /(\mathrm{Cr}+\mathrm{Al})$ values of 11.6-48.9. These features are consistent with depletion caused by removal of a basaltic partial melt from more normal garnet lherzolite.

\section{Mineralogy and Chemistry of the Altered Samples}

Six different peridotite nodules (PTH 108, 202 204 and 404 of Carswell et al (1979), plus PTH 58 and 516 courtesy of B. Harte and M.J. O'Hara) were the subject of further study because of their unusual mineralogy and the textural associations

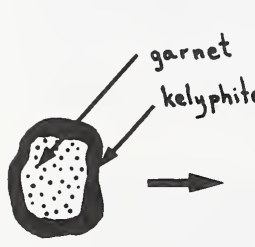

A

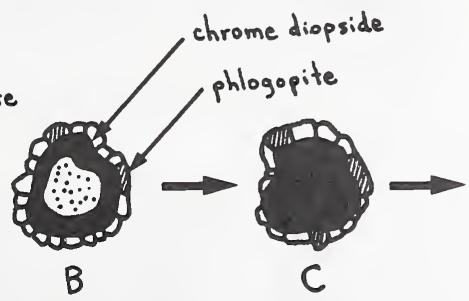

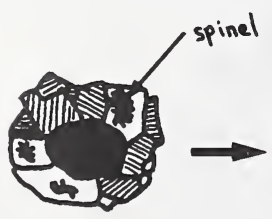

D

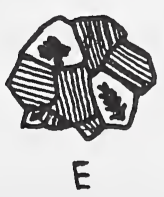

Figure 1

\section{$2 \mathrm{~mm}$}

involving those minerals. Normal PTH nodules contain some chrome pyrope garnet, usually with a rim of fine-grained kelyphite attributable to rapid alteration in the ascending kimberlite (Fig. 1A). In sample PTH 58 chrome diopside occurs as rare discrete grains in the rock, but more significantly as a collar of grains, with clear cores and cloudy, pitted margins, around the garnets. This collar also contains small amounts of phlogopite and tiny euhedral spinels. The garnet may be partially kelyphitized (PTH 58, Fig. 1B) or wholly kelyphitized (PTH 404, Fig. 1C). In sample PTH 204 (Fig. 1D), the collars around a kelyphitized garnet core are considerably wider, coarser grained, and both phlogopite and spinel are more abundant.

The clinopyroxene and phlogopite show a mosaic

PTH 58 (COLLAR)

\begin{tabular}{|c|c|c|c|c|c|c|}
\hline & $\underline{\mathrm{CPX}}$ & PHL & $\underline{S P}$ & CPX & PHL & $\underline{S P}$ \\
\hline $\mathrm{SiO}_{2}$ & 55.22 & 41.16 & - & 54.51 & 40.26 & - \\
\hline $\mathrm{TiO}_{2}$ & - & 0.29 & 0.96 & - & 0.22 & - \\
\hline $\mathrm{Al}_{2} \mathrm{O}_{3}$ & 2.52 & 13.18 & 9.45 & 4.45 & 14.92 & 14.8 \\
\hline $\mathrm{Cr}_{2} \mathrm{O}_{3}$ & 2.95 & 1.03 & 54.08 & 3.10 & 1.11 & 53.7 \\
\hline $\mathrm{FeO}$ & 2.04 & 2.60 & 18.94 & 1.99 & 2.31 & 18.0 \\
\hline Mno & - & - & 0.16 & - & - & - \\
\hline $\mathrm{MgO}$ & 15.95 & 25.00 & 13.20 & 13.60 & 24.22 & 13.6 \\
\hline $\mathrm{CaO}$ & 19.06 & - & 0.10 & 19.95 & - & - \\
\hline $\mathrm{Na}_{2} \mathrm{O}$ & 2.61 & 1.16 & - & 3.29 & 0.80 & - \\
\hline $\mathrm{K}_{2} \mathrm{O}$ & - & 9.80 & - & - & 9.83 & - \\
\hline OTAL & 35 & 94.22 & .89 & .89 & 93.67 & 0.10 \\
\hline
\end{tabular}

PTH 108 (POOL)

\begin{tabular}{|c|c|c|c|}
\hline & $\underline{\mathrm{CPX}}$ & PHL & $\underline{S P}$ \\
\hline $\mathrm{iO}_{2}$ & 54.31 & 42.48 & - \\
\hline $\mathrm{iO}_{2}$ & - & 0.23 & 0.73 \\
\hline $1_{2} \mathrm{O}_{3}$ & 1.28 & 12.38 & 5.35 \\
\hline $\mathrm{C}_{2} \mathrm{O}_{3}$ & 3.11 & 0.88 & 59.90 \\
\hline 20 & 2.37 & 2.71 & 22.61 \\
\hline 10 & 0.11 & - & 0.55 \\
\hline 0 & 16.46 & 26.49 & 11.10 \\
\hline & 20.53 & - & - \\
\hline & 2.14 & - & - \\
\hline & - & 10.03 & - \\
\hline
\end{tabular}

TOTAL $100.31 \quad 95.20 \quad 100.24$

Table 1. 
texture, and the clinopyroxene and spinel often show a symplectic relationship. In addition, the phlogopite shows wavy extinction and some kink banding. Finally, in PTH 108, 202 and 516, garnets are absent and all that remains in their place are pools of coarse-grained phlogopite, chrome diopside, and chrome-rich spinels (Fig. 1E). Phlogopite is generally the most abundant phase, and the chrome diopsides are characterized by clear cores and cloudy rims.

Representative analyses of the collar and pool minerals are summarized in Table 1.

Single pyroxene thermobarometry (Mercler 1980) on the collar and pool chrome diopsides might be expected to show equilibrium conditions different from those obtained for more normal nodules from Pipe 200 (Carswell et al. 1979; Mitchell et al. 1980), but the excess of $\mathrm{Na}$ over Al (cations) in these pyroxenes proved to be unsultable for that particular calculation. The phlogopites of the collars and pools are primary according to the classification of Carswell (1975), and this is interpreted to mean that they are of earlier mantle, rather than of later diatreme, origin.

\section{Collar and Pool Formation}

From the textural relations shown in Fig. 1, it is clear that the collars and pools have formed largely at the expense of garnet. Such fertile clots of minerals could not have survived the partial melting event as demanded by the depletion of the whole-rock composition, therefore collar and pool formation post-dated the partial melting event. The coarse-grained texture of the collars and pools, the deformation of the phlogopites and the primary chemical compositions of the phlogopites all suggest that collar and pool formation predated the kimberlite diatreme event. Thus the time of formation of the collars and pools is bracketed between the depletion and diatreme events.

It is possible that the collars may represent the products of the retrograde reaction, olivine + garnet $\rightarrow$ opx (grain growth outside the collar) + cpx + spinel, with either decreasing pressure in an ascending diapir, or with decreasing temperature after the partial melting event, or both. However, the presence of minor phlogopite in the collars suggests that metasomatic fluids rich in $\mathrm{H}_{2} \mathrm{O}$ and $\mathrm{K}_{2} \mathrm{O}$

were at least involved in inftiating garnet breakdown. The pools, with up to $80 \%$ phlogopite after garnet, are clearly the result of mantle metasomatism, and from the range of textures developed (Fig. 1), this reaction had progressed to different degrees. Although there is no evidence in these samples to help distinguish between the metasomatismbefore-magmatism model of Boettcher et al. (1979), and the metasomatism-after-magmatism model of Wyllie (1980), it is believed that the extent of collar and pool formation in the Pipe 200 nodules is more likely a function of the distance of these rocks from a water-saturated magma (either kimberlite, or fractionating to become kimberlite) prior to their incorporation into that magma and rapid ascent to the surface.

\section{References}

Boettcher, A.L., J.R. O'Neil, K.E. Windom, D.C. Stewart and H.G. Wilshire (1979): In "The Mantle Sample: Inclusions in Kimberlites and Other Volcanics", Boyd, F.R. and Meyer, H.O.A., eds. Am. Geophys. Union Special Publ. Vol 2, 173-182.

Carswell, D.A. (1975): Phys. Chem. Earth 9, 417-430.

Carswell, D.A., D.B. Clarke and R.H. Mitchell (1979): In "The Mantle Sample: Inclusions in Kimberlites and Other Volcanics", Boyd, F.R. and Meyer, H.O.A., eds. Am. Geophys. Union Special Publ. Vol. 2, $127-144$.

Mercier, J.C.C. (1980): Tectonophysics 70, 1-37.

Mitchell, R. H., D.A. Carswell and D.B. Clarke (1980): Contrib. Min. Pet. 72, 205-217.

Wyll1e, P.J. (1980): J. Geophys. Res. 85, 6902-6910.

\section{NATURE OF THE CONTINENTAL UPPER-MANTLE/LOWER-CRUST TRANSITION BENEATH KILBOURNE HOLE, NEW MEXICO}

\section{BUSSOD}

Department of Earth and Space Scknccs unversily it Calforma. Los Angeles CA 90024

Models of the continental upper mantle-lower crust transition zone are principally constrained by the study of xenoliths brought to the earth's surface by basaltic magmas. However, because xenoliths occur in restricted tectonic environments closely associated with basaltic volcanism, they do not necessarily represent a typical sample of the 1 ithosphere but a modiffed product formed in response to the thermal evolution of such regions. The information obtained from xenoliths is limited by our ability to reconstruct the mechanical and thermal history of the samples. Xenoliths of both crustal and mantle rocks are abundant at Kilbourne Hole and help to constrain the rheology, composition and thermal regime of the crust-mantle boundary beneath the Rio Grande Rift.

\section{Crustal Xenoliths}

The crustal xenoliths from Kilbourne Hole point to the existence of a granulite facies metamorphic complex composed of garnet and two-pyroxene granulites, garnet orthopyroxenites, anorthosites and charnockites (Padovani and Carter, 1977). Estimated peak temperatures of $1000-1100^{\circ} \mathrm{C}$ intimate that the lower crust was partially melted and recrystallized as fine-grained anhydrous granulites. The transient nature of this thermal event is inferred from local mineral disequilibrium (zoning) of the constituent mineral phases, indicating subsequent slow cooling (Padovani and Hart, 1981).
Mantle Xenoliths

The mantle xenoliths include dunites, harzburgites, both members of the Cr-diopside spinel iherzolite

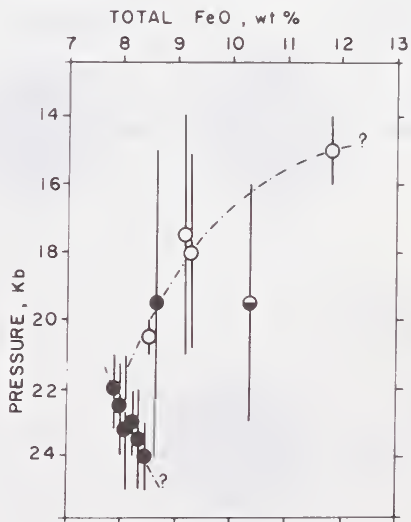

Fig. 1. Bulk FeO vs. average of two independent barometric estimates for granuloblastic (open circles), protogranular (filled circles) and composite xenoliths. 